\title{
Pola Resistensi Bakteri Penyebab Sepsis Neonatorum di Instalasi Perawatan Neonatus RSUD Arifin Achmad Riau
}

Nazardi Oyong, Dewi Anggraini, Karina

Rumah Sakit Umum Daerah Arifin Achmad, Pekanbaru

Latar belakang. Sepsis neonatorum masih menjadi kendala utama di bidang pelayanan dan perawatan neonatus. Diperlukan pemberian antibiotik empirik yang tepat dapat menurunkan angka kematian. Namun, terapi empirik yang tepat harus berdasarkan pola resistensi di tempat tersebut

Tujuan. Mengetahui pola resistensi bakteri dari kultur darah pasien sepsis neonatal.

Metode. Desain penelitian deskriptif retrospektif. Semua data hasil kultur dan uji resistensi antibiotik dari spesimen darah neonatus tersangka sepsis yang dirawat di Instalasi Perawatan Neonatus RSUD Arifin Achmad Provinsi Riau periode Januari sampai Desember 2014 dimasukkan dalam penelitian.

Hasil. Didapatkan 568 pemeriksaan kultur darah neonatus yang diduga sepsis, dengan hasil kultur darah positif 196 (34,51\%). Mikroorganisme terbanyak yang ditemukan yaitu Coagulase negative Staphylococci (CoNS) (29,08\%), Candida sp (15,21\%), B. cepacia (12,76\%), A. baumanii (9,18\%) dan K. pneumoniae (8,16\%). Bakteri Gram positif paling sensitif dengan vancomycin dan linezolid, sedangkan bakteri Gram negatif paling sensitif dengan meropenem, amikacin dan tigecycline.

Kesimpulan. Hasil kultur darah positif adalah 34,5\%. Mikroorganisme yang paling banyak yaitu Coagulase negative Staphylococci, Candida sp, B. cepacia, A. baumanii dan K. pneumoniae. Bakteri Gram positif paling sensitif dengan vancomycin dan linezolid. Bakteri Gram negatif paling sensitif dengan meropenem, amikacin dan tigecycline. Sari Pediatri 2016;17(6):435-40.

Kata kunci: sepsis neonatorum, pola resistensi

\section{Resistance Pattern of Bacteria Cause Neonatal Sepsis in Neonatal Care Installation of Arifin Achmad General Hospital Riau}

Nazardi Oyong, Dewi Anggraini, Karina

Background. Neonatal sepsis remains a major constraint in neonatal care. Appropriate empiric antibiotics treatment can reduce mortality rate caused by neonatal sepsis, however is should be it should be based on the pattern of isolated bacterial resistance in each setting.

Objective. To know the resistance pattern of bacteria isolated from blood culture of neonatal sepsis patients.

Method. This was a descriptive retrospective study. All culture and antibiotic resistance testing result of bacteria isolated from blood specimens of suspected neonatal sepsis patients who were treated at the Neonatal Care Installation, were included in this study. The period of this study was from January until December 2014.

Results. The positivity rate of blood culture from suspected neonatal sepsis was $34.5 \%$. The most prevalence microorganism isolated were coagulase negative Staphylococci (CoNS) (29.08\%), Candida sp (15.21\%), B. cepacia (12.76\%), A. baumannii (9.18\%) and K. pneumoniae. Gram-positive bacterias were mostly sensitive to vancomycin and linezolid, while Gram negative bacterias were mostly sensitive to meropenem, amikacin and tigecycline.

Conclusion. Positivity rate of blood culture was 34.5\%. The most prevalence microorganism isolated was Coagulase negative staphylococci, Candida sp, B. cepacia, A. baumannii and $K$. pneumoniae. Gram-positive bacterias mostly were sensitive to vancomycin and linezolid, while Gram negative bacterias mostly susceptible to meropenem, amikacin and tigecycline. Sari Pediatri 2016;17(6):435-40.

Keywords: neonatal sepsis, resistance patterns

\footnotetext{
Alamat korespondensi: Dr. Dewi Anggraini, SpMK, Dr. Nazardi Oyong, Sp.A. RSUD Arifin Achmad. Jl. Diponegoro No.2, Pekanbaru, Riau. E-mail: nazardio@yahoo.com
} 
S epsis neonatorum masih menjadi kendala utama di bidang pelayanan dan perawatan neonatus. Menurut data World Health Organization (WHO), secara global terdapat 5 juta kematian neonatus setiap tahunnya dengan angka mortalitas mencapai 34 per 1000 kelahiran hidup, dan $98 \%$ di antaranya terjadi di negara berkembang. ${ }^{1}$ Angka kejadian sepsis neonatus di negara maju 1-4 per 1000 kelahiran hidup dengan angka kematian 10,3\%, lebih rendah dibandingkan negara berkembang yang mencapai $10-50$ per 1000 kelahiran hidup dengan angka kematian 12\%-68\%. ${ }^{2}$ Di Indonesia, angka kematian neonatus 34 per 1000 kelahiran hidup. ${ }^{3}$

Menurut Mondal dkk, ${ }^{4}$ hasil kultur darah terbanyak berasal dari Gram positif. Staphylococcus koagulase negatif menjadi yang paling banyak ditemukan, kemudian diikuti Klebsiella pneumoniae, Acinetobacter baumanii, Staphylococcus aureus dan Pseudomonas aeruginosa. Semua isolat sensitif terhadap gentamycin, tetapi $75 \%$ telah resisten terhadap ampicillin. Di Rumah Sakit Cipto Mangunkusumo, Juniatiningsih $\mathrm{dkk}^{5}$ menemukan Acinetobacter colcoaceticus merupakan bakteri yang paling banyak ditemukan. Pada beberapa penelitian, golongan Enterobacteriaceae menjadi yang paling banyak ditemukan, seperti penelitian Putri $\mathrm{dkk}^{6}$ di RSUP Dr. M. Djamil Padang yang menemukan Klebsiella sp 79,2\%. Aletayeb dkk ${ }^{7}$ mendapatkan $K$. pneumoniae $46,4 \%$. Berdasarkan data hasil penelitian di RSUP H. Adam Malik, Medan, diperoleh bakteri yang paling sering menjadi penyebab infeksi, yaitu Staphylococcus sp, Pseudomonas sp dan Enterobacter sp. Bakteri tersebut masih sensitif terhadap vankomisin, amikasin, dan meropenem. ${ }^{8}$

Sepsis pada neonatus memerlukan penanganan dan penegakan diagnosis yang tepat agar dapat menurunkan angka kematian. Pemeriksaan kultur darah merupakan baku emas diagnosis sepsis neonatus, tetapi hasil pemeriksaan baru dapat diketahui setelah 3-5 hari. ${ }^{9}$ Kultur darah dilakukan untuk mengetahui bakteri penyebab sekaligus melakukan uji kepekaan antibiotik. ${ }^{8}$ Sebelum hasil pemeriksaan kultur keluar, diberikan terapi antibiotik empirik. Pemberian antibiotik empirik yang tepat pada sepsis neonatorum dapat menurunkan angka kematian. Terapi empirik yang tepat harus berdasarkan pola resistensi di tempat tersebut. Penggunaan antibiotik yang tidak rasional juga dapat memicu terjadinya resistensi bakteri. ${ }^{10}$

Penelitian ini dilakukan untuk mengetahui pola bakteri dan pola resistensi terhadap antibiotik yang diisolasi dari kultur darah neonatus tersangka sepsis di Instalasi Perawatan Neonatus RSUD Arifin Achmad provinsi Riau.

\section{Metode}

Desain penelitian yang dilakukan adalah deskriptif retrospektif. Semua data hasil kultur dan uji resistensi antibiotik dari spesimen darah neonatus tersangka sepsis yang dirawat di Instalasi Perawatan Neonatus RSUD Arifin Achmad Provinsi Riau periode 01 Januari-31 Desember 2014 dimasukkan dalam penelitian. Pemeriksaan kultur dan uji resistensi dilakukan di Bagian Mikrobiologi Laboratorium Patologi Klinik RSUD Arifin Achmad Provinsi Riau. Pemeriksaan kultur darah dengan alat BacT/Alert Blood Culture System, sedangkan identifikasi dan uji resistensi digunakan Vitek 2 Compact. Data diolah dengan software WHONET 5.6 kemudian disajikan secara deskriptif dengan tabel distribusi frekuensi. Penelitian ini telah mendapat lolos kaji etik oleh Unit Etika Penelitian Kedokteran dan Kesehatan Fakultas Kedokteran Universitas Riau.

\section{Hasil}

Didapatkan 568 pemeriksaan kultur darah neonatus yang diduga sepsis, dengan hasil kultur darah positif 196 (34,51\%). Mikroorganisme terbanyak yang ditemukan, yaitu Coagulase negative Staphylococci (CoNS) (29,08\%), Candida sp (15,21\%), B. cepacia (12,76\%), A. baumanii (9,18\%), K. pneumoniae (8,16\%), E. coli (4,08\%), E. aerogenes (3,57\%), Serratia marcescens $(3,06 \%), S$. aureus $(3,06 \%)$, Pseudomonas aeruginosa (2,04\%) dan E. cloacae (2,04\%) (Tabel 1).

Coagulase negative Staphylococci paling sensitif terhadap vancomycin, linezolid, dan tigecycline masingmasing 100\%, hanya 19,29\% yang sensitif dengan cefoxitine, artinya hanya19,29\% yang sensitif dengan semua antibiotik beta laktam. Burkholderia cepacia memiliki sensitivitas yang baik terhadap meropenem, ceftazidime dan trimetropim/ sulfamethoxazole masingmasing 100\%. Acinetobacter baumanii paling sensitif terhadap amikacin sebesar 50\%, sedangkan dengan meropenem hanya 33\%. Klebsiella pneumoniae paling sensitif terhadap tigecycline (100\%) dan amikacin $(81,25 \%)$, sensitifitasnya dengan golongan sefalosporin 
Tabel 1. Distribusi mikroorganisme penyebab sepsis $(\mathrm{n}=196)$

\begin{tabular}{llcc}
\hline No. & Mikoorganisme & Jumlah isolat & $(\%)$ \\
\hline 1. & Coagulase negative Staphylococci (CoNS) & 57 & 29,08 \\
2. & Candida sp & 30 & 15,31 \\
3. & Burkholderia cepacia & 25 & 12,76 \\
4. & Acinetobacter baumannii & 18 & 9,18 \\
5. & Klebsiella pneumoniae & 16 & 8,16 \\
6. & Escherichia coli & 8 & 4,08 \\
7. & Enterobacter aerogenes & 7 & 3,57 \\
8. & Serratia marcescens & 6 & 3,06 \\
9. & Staphylococcus aureus & 6 & 3,06 \\
10. & Pseudomonas aeruginosa & 4 & 2,04 \\
11. & Enterobacter cloacae & 4 & 2,04 \\
12. & Sphingomonas paucimobilis & 3 & 1,53 \\
13. & Acinetobacter lwoffii & 2 & 1,02 \\
14. & Lain-lain & 10 & 5,1 \\
\hline & Total & 196 & $100,00 \%$ \\
\hline
\end{tabular}

Tabel 2. Pola resistensi antibiotik

\begin{tabular}{|c|c|c|c|c|c|c|c|c|c|c|}
\hline \multirow[t]{2}{*}{ Antibiotik } & \multicolumn{10}{|c|}{ Sensitifitas terhadap antibiotik (\%(n)) } \\
\hline & CoNS & B. cepacia & $\begin{array}{c}A . \\
\text { baumanii }\end{array}$ & $\begin{array}{c}K . \\
\text { pneumoniae }\end{array}$ & E. coli & $\begin{array}{c}E . \\
\text { aerogenes }\end{array}$ & $\begin{array}{c}S . \\
\text { marcescens }\end{array}$ & S. aureus & $\begin{array}{c}P . \\
\text { aeruginosa }\end{array}$ & $\begin{array}{c}\text { E. } \\
\text { cloacae }\end{array}$ \\
\hline Amoxicillin & $3,5(54)$ & & & 0 (14) & $37,5(6)$ & $0(7)$ & $0(4)$ & $0(3)$ & & $0(2)$ \\
\hline $\begin{array}{l}\text { Amoxicillin/ } \\
\text { Clavulanic acid }\end{array}$ & & & & & & & & $83,33(5)$ & & \\
\hline $\begin{array}{l}\text { Ampicillin/ } \\
\text { Sulbactam }\end{array}$ & & $0(25)$ & $44,44(17)$ & $6,25(16)$ & $62,5(7)$ & $0(7)$ & $0(6)$ & $83,33(5)$ & $0(4)$ & $25(4)$ \\
\hline $\begin{array}{l}\text { Piperacillin/ } \\
\text { tazobactam }\end{array}$ & $19,29(54)$ & $88(23)$ & $11,1(16)$ & $25(16)$ & $87,5(8)$ & $0(7)$ & $100(6)$ & $66,67(5)$ & $0(4)$ & $50(4)$ \\
\hline Cefazolin & $19,29(54)$ & $0(25)$ & $0(17)$ & $6,25(16)$ & $75(8)$ & $0(7)$ & $16,67(6)$ & $16,67(6)$ & $0(4)$ & $25(4)$ \\
\hline Ceftazidime & $19,29(54)$ & $36(25)$ & $0(17)$ & $6,25(16)$ & $62,5(8)$ & $0(7)$ & $83,33(6)$ & $83,33(6)$ & $0(4)$ & $25(4)$ \\
\hline Cefepime & $19,29(53)$ & $84(25)$ & $17(17)$ & $6,25(16)$ & $75(8)$ & $0(7)$ & $83,33(6)$ & $83,33(6)$ & $0(4)$ & $50(4)$ \\
\hline Cefoxitin & $19,29(54)$ & & & & & & & $83,33(6)$ & & \\
\hline Meropenem & $19,29(54)$ & $100(25)$ & $33,3(17)$ & $33,3(17)$ & $62,5(16)$ & $100(8)$ & $100(7)$ & $100(6)$ & $83,33(6)$ & $0(4)$ \\
\hline Aztreonam & & $8(24)$ & $0(17)$ & $6,25(16)$ & $62,5(6)$ & $0(6)$ & $83,33(6)$ & & $0(4)$ & $33(3)$ \\
\hline Amiikacin & & $0(25)$ & $50(16)$ & $81,25(16)$ & $100(8)$ & $100(7)$ & $100(6)$ & & $25(4)$ & $100(4)$ \\
\hline Gentamycin & $36,84(56)$ & $4(25)$ & $44,44(17)$ & $18,75(16)$ & $62,5(8)$ & $0(7)$ & $83,33(6)$ & $83,33(6)$ & $0(4)$ & $50(4)$ \\
\hline Ciprofloxacin & $49,12(57)$ & $0(25)$ & $44,44(17)$ & $31,25(16)$ & $75(8)$ & $100(7)$ & $83,33(6)$ & $83,33(6)$ & $75(4)$ & $50(4)$ \\
\hline Levofloxacin & $49,12(57)$ & $84(24)$ & 38,8 (13) & $43,75(14)$ & $75(7)$ & $100(7)$ & $100(4)$ & $83,33(6)$ & $75(4)$ & $100(3)$ \\
\hline Tigecycline & $100(57)$ & $4(25)$ & $44,44(17)$ & $100(16)$ & $100(8)$ & $100(7)$ & $83,33(6)$ & $100(6)$ & $0(4)$ & $100(4)$ \\
\hline $\begin{array}{l}\text { Trimetropim/ } \\
\text { sulfamethoxazol }\end{array}$ & $56,87(57)$ & $100(25)$ & $22,2(17)$ & $50(16)$ & $62,5(8)$ & $0(6)$ & $100(6)$ & $100(6)$ & $25(4)$ & $25(4)$ \\
\hline Clindamycin & $31,57(55)$ & & & & & & & $83,33(6)$ & & \\
\hline Vancomycin & $100(57)$ & & & & & & & $100(6)$ & & \\
\hline Linezolide & $100(57)$ & & & & & & & $100(6)$ & & \\
\hline
\end{tabular}


generasi ketiga dan keempat hanya 6,25\%, serta dengan meropenem sebesar $62,5 \%$.

Escherichia coli memberikan hasil sensitivitas yang baik terhadap meropenem, amikacin dan tigecycline masing-masing $100 \%$. Enterobacter aerogenes paling sensitif terhadap meropenem, amikacin, ciprofloxacin, tigecycline dan levofloxacin masing-masing 100\%. Serratia marcescens paling sensitif terhadap meropenem, piperacillin/ tazobactam, amikacin, levofloxacin dan trimetoprim/ sulfamethoxazole masing-masing 100\%. Pseudomonas aeruginosa paling sensitif terhadap antibiotik golongan fluorokuinolon, yaitu ciprofloxacin dan levofloxacin masing-masing $75 \%$.

Staphylococcus aureus sensitif dengan cefoxitin $83,33 \%$, artinya $83,33 \%$ dari S.aureus yang ada bukan MRSA, sedangkan sisanya adalah MRSA. S. aureus paling sensitif dengan vancomycin, linezolid, tigecycline dan trimetropim/ sulfamethoxazole masingmasing $100 \%$.

\section{Pembahasan}

Pada penelitian ini kultur darah positif adalah 34,51\%. Hasil tersebut lebih rendah dari pada penelitian Anggraini ${ }^{11}$ di RSUD Arifin Achmad pada Juli Desember 2013 yaitu 53,39\%. Demikian juga dengan penelitian Rasyidah di RSUD dr. Pirngadi Medan $46,5 \%{ }^{9}$ dan penelitian Kardana di RSUP Sanglah Denpasar $48 \% .^{12}$

Persentase hasil kultur positif yang lebih rendah dapat dipengaruhi oleh beberapa faktor, seperti cara pengambilan spesimen, volume darah yang tidak adekuat, ${ }^{13}$ metode yang digunakan, serta kriteria seleksi pasien yang akan dilakukan kultur darah yang berbeda di setiap rumah sakit. Kultur darah merupakan hal yang rutin untuk semua pasien tersangka sepsis, sebelum pemberian antibiotik empirik Di RSUD Arifin Achmad. Metode yang digunakan adalah sistem otomatis BacT/ Alert Blood Culture System ${ }^{14}$ dengan jumlah pengambilan kultur darah hanya di satu tempat. Bakteri yang kami temukan didominasi oleh CoNS. Hal tersebut sesuai dengan penelitian Anggarini ${ }^{12}$ di Bagian Mikrobiologi RSUD Arifin Achmad pada Juli - Desember 2013 dan penelitian Mondal dkk, ${ }^{4}$ yaitu CoNS ditemukan masingmasing $31,34 \%$ dan $21,2 \%$, serta Sianturi $\mathrm{dkk}^{8}$ yang melaporkan Staphylococcus sp sebesar 43\%.

Penelitian lain mendapatkan hasil berbeda. Juniatiningsih $\mathrm{dkk}^{5}$ di RS. Cipto Mangunkusumo melaporkan Acinetobacter colcoaceticus merupakan bakteri terbanyak ditemukan. Pada beberapa penelitian, golongan Enterobacteriaceae menjadi yang paling banyak ditemukan, seperti penelitian Putri $\mathrm{dkk}^{6} \mathrm{di}$ RSUP Dr. M. Djamil yang melaporkan Klebsiella $s p 79,2 \%$, Aletayeb $\mathrm{dkk}^{7}$ melaporkan $K$. pneumoniae $46,4 \%$.

Coagulase negative Staphylococci dilaporkan sebagai penyebab sepsis awitan lambat tersering. ${ }^{15}$ Bakteri tersebut menyebabkan bakteremia yang berhubungan dengan penggunaan indwelling devices. ${ }^{10}$ Staphylococcus koagulase negatif merupakan flora normal di kulit. Oleh karena itu, dibutuhkan pemeriksaan di beberapa tempat untuk mengetahui apakah bakteri ini hanya kontaminasi atau merupakan penyebab sepsis. Pada penelitian kami, tidak dapat dibedakan apakah CoNS yang ditemukan merupakan kontaminasi atau penyebab karena sampel darah hanya diambil di satu tempat sebanyak satu botol.

Coagulase negative Staphylococci pada penelitian kami telah resisten terhadap cefoxitin dan antibiotik beta laktam lainnya dengan sensitivitas masing-masing $19,29 \%$, tetapi memiliki sensitivitas yang baik terhadap vancomycin, linezolid, dan tigecycline. Hal tersebut sesuai dengan laporan penelitian Sharma $\mathrm{dkk}^{16}$ dan Khan $\mathrm{dkk}^{17} \mathrm{di}$ India. Agak berbeda dengan penelitian Kardana di RSUP Sanglah Denpasar yang melaporkan bahwa CoNS paling sensitif terhadap meropenem dan fosfomycin masing-masing $87,5 \%$, kemudian cefoperazon $73,3 \%$, piperacillin 61,5\%, ciprofloxacin 57,9\%, dan gentamycin $57,1 \% .{ }^{12}$ Berdasarkan literatur pilihan, terapi paling baik untuk CoNS adalah vancomycin. ${ }^{18}$

Burkholderia cepacia paling sensitif terhadap meropenem, ceftazidime, trimetropim/sulfamethoxazole masing-masing $100 \%$. Hasil serupa dilaporkan oleh Mutlu $\mathrm{dkk}^{19}$ di Turki, B. cepacia paling sensitif terhadap imipenem dan meropenem masing-masing $100 \%$, amikacin, ciprofloxacin dan trimetropim/ sulfamethoxazole masing-masing $100 \%$ serta ceftazidime $82 \%$. Demikian juga laporan penelitian MarambaLazarte $\mathrm{dkk}^{20}$ di Filipina, hasil paling sensitif juga terhadap golongan carbapenem, meropenem sebesar 75\% dan imipenem 33\%, diikuti oleh cefuroxim, ceftazidime, ceftriaxone, piperacillin/ tazobactam dan cotrimoxazole. Pilihan terapi untuk B. cepacia berdasarkan literatur adalah antibiotik golongan carbapenem, yaitu meropenem. ${ }^{18}$

Acinetobacter baumanii telah resisten dengan antibiotik golongan carbapenem, yaitu meropenem 
sebesar 33,3\%. Hal tersebut berbeda dengan laporan penelitian Kardana ${ }^{12}$ di RSUP Sanglah Denpasar, A. baumanii masih cukup baik terhadap meropenem dengan sensitivitas $72,7 \%$. Sementara itu, Mutlu $\mathrm{dkk}^{19}$ melaporkan $A$. baumanii paling sensitif terhadap meropenem sebesar 100\% dan imipenem 88\%. Pada penelitian kami, $A$. baumanii masih sensitif dengan golongan aminoglikosida, yaitu amikacin dengan sensitivitas 50\%. Hasil serupa dapat dilihat pada laporan penelitian Ahmed $\mathrm{dkk}^{21}$ di Doha, A. baumanii paling sensitif terhadap amikacin dan meropenem masing-masing $100 \%$.

Sensitifitas $K$. pneumoniae dengan sefalosporin generasi ketiga, yaitu ceftriaxone sangat rendah (6,25\%). Sesuai dengan laporan penelitian Khan $\mathrm{dkk}^{17}$ dan Movahedian $\mathrm{dkk}^{22}$ di Iran, yaitu masing-masing 23,07\% dan $31 \%$. K. pneumoniae penghasil enzim penghidrolisis antibiotik beta laktam yang mengandung gugus oksimino, seperti seftazidim, seftriakson, sefotaksim atau aztreonam dinamakan ESBL (Extended-spectrum beta lactamase).$^{23}$ Pada penelitian kami, $K$. pneumoniae yang sensitif terhadap meropenem sebesar $62,5 \%$. Sesuai dengan laporan penelitian Parveen $\mathrm{dkk}^{24}$ di India, yaitu 43,6\%. Berbeda dengan penelitian Aletayeb dkk, ${ }^{7}$ Kardana, ${ }^{12}$ dan Mutlu dkk ${ }^{19}$ yang melaporkan sensitifitas dengan carbapenem tinggi, masing-masing 90\%, 100\%, dan $100 \%$.

Persentase MRSA 16,67\%, lebih rendah dibanding laporan penelitian Healy $\mathrm{dkk}^{25}$ di Texas (47\%) dan Gandhi dkk ${ }^{26}$ di India $(31,25 \%)$. Pada penelitian kami, S. aureus paling sensitif terhadap vancomycin, linezolid, tigecycline, dan trimetroprim/sulfamethoxazole. Hampir sama dengan laporan penelitian Sharma dkk, ${ }^{18}$ S. aureus paling sensitif terhadap vancomycin sebesar $100 \%$ dan amikacin $82,35 \% .{ }^{16}$ Pilihan terapi untuk MRSA adalah vancomycin.

Dari penelitian ini dapat dilihat bahwa tigecycline merupakan salah satu antibiotik yang paling sering menunjukkan sensitivitas baik. Tigecycline merupakan antibiotik glisiklin pertama hasil dari pengembangan antibiotik golongan tetrasiklin. Akan tetapi, pada wanita hamil dan menyusui serta pasien di bawah usia 8 tahun, penggunaan tigecycline tidak dianjurkan. ${ }^{27}$ Pertumbuhan tulang dapat terhambat pada fetus dan anak. Bahaya terutama terjadi mulai pertengahan masa hamil sampai dan sering berlanjut hingga umur 7 tahun atau lebih, tergantung dari jumlah dan lama penggunaan. ${ }^{28}$ Akan tetapi, pada situasi tertentu di saat terjadi kekurangan pilihan terhadap antibiotik yang akan digunakan seperti telah resistennya $K$. pneumoniae dan E. coli terhadap golongan carbapenem, penggunaan tigecycline dapat menjadi alternatif. ${ }^{29}$

\section{Kesimpulan}

Hasil kultur darah positif pada neonatus tersangka sepsis adalah $34,5 \%$. Bakteri terbanyak ditemukan adalah Gram positif, yaitu Coagulase negative Staphylococci, kemudian diikuti oleh Candida sp, dan bakteri Gram negatif yaitu B. cepacia, A. baumanii, $K$. pneumoniae dan E. coli. Bakteri Gram positif paling sensitif dengan vancomycin dan linezolid. Bakteri Gram negatif paling sensitif dengan meropenem, amikacin dan tigecycline.

\section{Daftar pustaka}

1. WHO. Perinatal mortality report. Geneva: WHO; 1996.

2. Wilar R, Kumalasari E, Suryanto DY, Gunawan S. Faktor risiko sepsis awitan dini. Sari Pediatri 2010;12: 265-9.

3. Wisnumurti DA. Performance of Neonatal Unit, Arifin Achmad Hospital Pekanbaru. Paediatr Indones 2012;52:356-61.

4. Mondal GP, Raghavan M, Bhat BV, Srinivasan S. Neonatal septicaemia among inborn and outborn babies in a Referral Hospital. Indian J Pediatr1991;58:529-33.

5. Juniatiningsih A, Aminullah A, Firmnsyah A. Profil mikroorganisme penyebab sepsis neonatorum di Departemen Ilmu Kesehatan Anak Rumah Sakit Cipto Mangunkusumo Jakarta. Sari Pediatri 2008;10:60-5.

6. Putri SI, Djamal A, Rahmatini. Sensitivitas bakteri penyebab sepsis neonatorum terhadap meropenem di NICU dan Perinatologi RSUP Dr M Djamil Padang. Jurnal Kesehatan Andalas 2014;3:477-81.

7. Aletayeb SMH, Khosravi AD, Dehdastian M, Kompani F, Mortazavi SM, Aramesh MR. Identification of bacterial agents and antimicrobial susceptibility of neonatal sepsis: A 54-months study in a tertiary Hospital. African J Microbiol Res 2011;5:528-31.

8. Sianturi P, Hasibuan BS, Lubis BM, Azlin Emil, Tjipta GD. Gambaran pola resistensi bakteri di Unit Perawatan Neonatus. Sari Pediatri 2012;13:431-6.

9. Aminullah A. Sepsis pada bayi baru lahir. Dalam: Kasim MS, Yunanto A, Dewi R, Sarosa GI, Usman A, penyunting. Buku Ajar Neonatologi Anak. Edisi ke-1. Jakarta: Ikatan Dokter Anak Indonesia; 2008.

10. Dzen SM, Santoso S, Roekistiningsih, Santosaningsih D. 
Perbedaan pola resistensi Staphylococcus koagulase negatif isolat darah terhadap antibiotika di RSU Dr Saiful Anwar Malang tahun 2000-2001 dengan 2004-2005. Jurnal Kedokteran Brawijaya 2005;21:127-31

11. Anggraini D. Hasil uji kepekaan mikroorganisme terhadap antibiotik Juli-Desember 2013. Pekanbaru: Laboratorium Mikrobiologi RSUD Arifin Achmad Prov. Riau;2014.

12. Kardana IM. Pola Kuman dan Sensitivitas Antibiotik di Ruang Perinatologi. Sari Pediatri 2011;12:381-5.

13. Connell TG, Relle Mhisti, Cowley Donna, Buttery JP, Curtis Nigel. How Reliable Is a Negative Blood Culture Result? Volume of Blood Submitted for Culture in Routine Practice in a Children's Hospital. Pediatrics 2007;119:891-6.

14. BacT/ Alert ${ }^{\oplus} 3 \mathrm{D}$ : Health Care. Diakses tanggal 12 Juni 2015. Diunduh dari: http://www. biomerieux-usa.com/clinical/ bact-alert-3d-healthcare.

15. H Yulidar, Martuti Sri, Sunyataningkamto. Pola kuman, sensitifitas antibiotik dan risiko kematian oleh kuman Staphylococcus coagulase negatif pada Sepsis Neonatorum di RS Dr Moewardi Surakarta. Sari Pediatri 2006;8:122-6.

16. Sharma CM, Agrawal RP, Sharan Hariom, Kumar Bijay, Sharma Deepti, Bhatia SS. Neonatal Sepsis: Bacteria and their susceptibility pattern towards antibiotics in Neonatal Intensive Care Unit. J Clin Diagnostic Res 2013;7:2511-3.

17. Khan SN, Joseph S. Neonatal sepsis: antibiotic sensitivity and resistance of commonly isolated pathogens in a Neonatal Intensive Care Unit of a Tertiary Care Hospital, South India. Int J Pharm Bio Sci 2012;3:802-9.

18. Levinson W. Review of medical microbiology and immunology. Edisi ke-13. San Francisco: McGraw-Hill Education; 2014.

19. Mutlu M, Aslan Y, Saygin B, Yilmaz G, Bayramoglu G, Koksal I. Neonatal sepsis caused a gram-negative bacteria in a Neonatal Intensive Care Unit: A six years analysis. HK J Paediatr (new series) 2011;16:253-7.
20. Gallardo EE, Lim JG, Lobo JJ, Aguilar CY. Etiology of neonatal sepsis in five urban hospitals in the Philippines. PIDSP Journal. 2011;12:5-85.

21. Ahmed A, Lutfi S, Al Hail M, Al Saadi M. antibiotic susceptibility pattern of microbial isolates from blood culture in the Neonatal Intensive Care Unite of Hamad Medical Corporation (HMC), Doha, Qatar. Asian J Pharm Clin Res 2013;6:191-5.

22. Movahedian AH, Moniri R, Mosayebi Z. Bacterial culture of neonatal sepsis. Iranian J Publ Health 2006;35:84-9.

23. Rupp M, Fey P. ESBL producing enterobacteriaceae: considerations ford, prevention and drug treatment. J Pubmed 2006;63:353-65.

24. Parveen RM, Harish BN, Parija SC. Emerging carbapenem resistance among nosocomial isolates of klebsiella pneumoniae in South India. Int J Pharma Bio Sci $2010 ; 1: 1-11$.

25. Healy CM, Hulten KG, Palazzi DL, Campbell JR, Baker CJ. Emergence of new strains of methicillin-resistant staphylococcus aureus in a neonatal intensive care unit. CID 2004;39:1460-6.

26. Gandhi S, Ranjan KP, Ranjan N, Sapre N, Masani M. Incidence of neonatal sepsis in a tertiary care hospital: An overview. Int J Med Sci Pub Health 2012;2:548-52.

27. Medikamen-Suplemen Buletin Rasional Tentang Kajian Obat Baru. Tigesiklin: antibiotik glisiklin pertama. Diakses tanggal 23 Januari 2015. Diunduh dari: https:// piolk.ubaya.ac.id.

28. Gunawan Sulistia Gan. Farmakologi dan terapi. Edisi ke-5. Jakarta: Departemen Farmakologi dan Terapeutik Fakultas Kedokteran Universitas Indonesia; 2007.

29. Tjay Tan Hoan, Rahardja Kirana. Obat-obat penting: khasiat, penggunaan, dan efek-efek sampingnya. Diakses tanggal 23 Januari 2015. Diunduh dari: https://books.google. co.id/books?id =TN8Q $\times$ BMHW6ICOrpg $=P A 77$ \& dq $=$ gentamisin

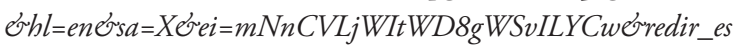
$c=y \# v=$ onepage $\mathrm{r} q=$ vankomisin $\delta \cdot f=$ false. 